\title{
Reaksi Pasar Dalam Bentuk Return Sebelum, Selama, dan Sesudah Peristiwa Piala Dunia Tahun 2014 pada Pasar Modal Asean
}

\author{
Ratih Pratiwi, Muhammad Yusuf \\ ${ }^{1}$ Universitas Pancasila, Jl. Srengseng Sawah, Jagakarsa, Jakarta Selatan 12640 \\ ${ }^{2}$ Indonesia Banking School, Jl. Kemang Raya No. 35 Kebayoran baru - Jakarta Selatan - 12730
}

I N F O A R T I K E L

\section{JEL Classification:}

G14

M20

Keywords:

world cup, return,

ASEAN, stock exchange, market reaction

\section{A $B$ S S T R $A$ A $C$ T}

Investor realized that the stock market gradually decreased during World Cup.The research aimed to analyze the return of market reaction which happenned before, during, and after World Cup 2014 on ASEAN stock market. The sample involved 181 companies were included in LQ-45, STI, FTSE BM KLCI, SET 50, PSEI index, which fulfilled the reseach criteria. The data analysis technique used was one sampel t-test with quantitative data. Based on the result, can be concluded that Indonesia and Thailand stock markets were higly effected by World Cup.

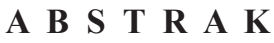

Investor mengetahui bahwa setiap piala dunia berlangsung, pergerakan saham melambat. Hal tersebut terbukti dengan terjadi penurunan return saham di pasar modal. Penelitian ini bertujuan untuk menganalisa reaksi pasar dalam bentuk return terjadi sebelum, selama dan sesudah piala dunia tahun 2014 pada pasar modal ASEAN. Sampel yang digunakan dalam penelitian ini sebanyak 181 perusahaan yang termasuk dalam indeks LQ-45, STI, FTSE BM KLCI, SET 50, PSEI dan memenuhi kriteria penelitian.Teknik analisa data menggunakan one sampel t-test dengan data kuantitatif. Hasil penelitian menemukan bukti bahwa pasar modal Indonesia dan Thailand sangat bereaksi terhadap peristiwa piala dunia tahun 2014.

\section{Pendahuluan}

Pasar modal Indonesia melalui Bursa Efek Indonesia telah menjadi bagian yang tak terpisahkan dari kegiatan bursa saham regional. Perubahan di suatu bursa akan ditransmisikan ke bursa di negara lain, di mana bursa yang lebih besar akan mempengaruhi bursa yang lebih kecil (Mansur, 2005:204). Keterkaitan antara bursa saham Indonesia dengan bursa saham luar negeri dapat dilihat ketika terjadi reaksi pasar berupa anomali.
Ketidaknormalan bisa terjadi pada pasar secara keseluruhan, tetapi bisa juga terjadi pada pergerakan saham saham tertentu. Anomali yang terjadi pada pasar secara keseluruhan dimana Indeks Harga Saham sebagai indikator perdagangan bergerak naik atau turun signifikan tanpa alasan yang jelas. Pergerakan indikator pasar yang kurang wajar ini biasanya terjadi pada waktu tertentu.

Anomali pasar yang terjadi lainnya yaitu pada peristiwa Piala Dunia. Ajang rutin yang pertama kali diselenggarakan pada tahun 1930 
di Uruguay dilaksanakan rutin setiap 4 tahun. Semua investor mengetahui bahwa setiap piala dunia berlangsung, pergerakan saham melambat. Penelitian yang dilakukan Kaplanski dan Levy (2008) membuktikan bahwa selama jangka waktu awal tahun 1950 sampai dengan akhir tahun 2007 dimana terdapat hasil yang negatif signifikan terhadap return indeks pasar modal Amerika Serikat selama 15 kali periode piala dunia tersebut.
Peningkatan indeks LQ-45 dapat dipengaruhi oleh reaksi para investor dalam menyikapi informasi di pasar modal. Informasi dapat berupa variabel akuntansi, pembagian deviden, dan laporan para analisis pasar modal.

Variabel akuntansi merupakan informasi akuntansi yang terdapat dalam laporan keuangan perusahaan dan mencerminkan kualitas kinerja

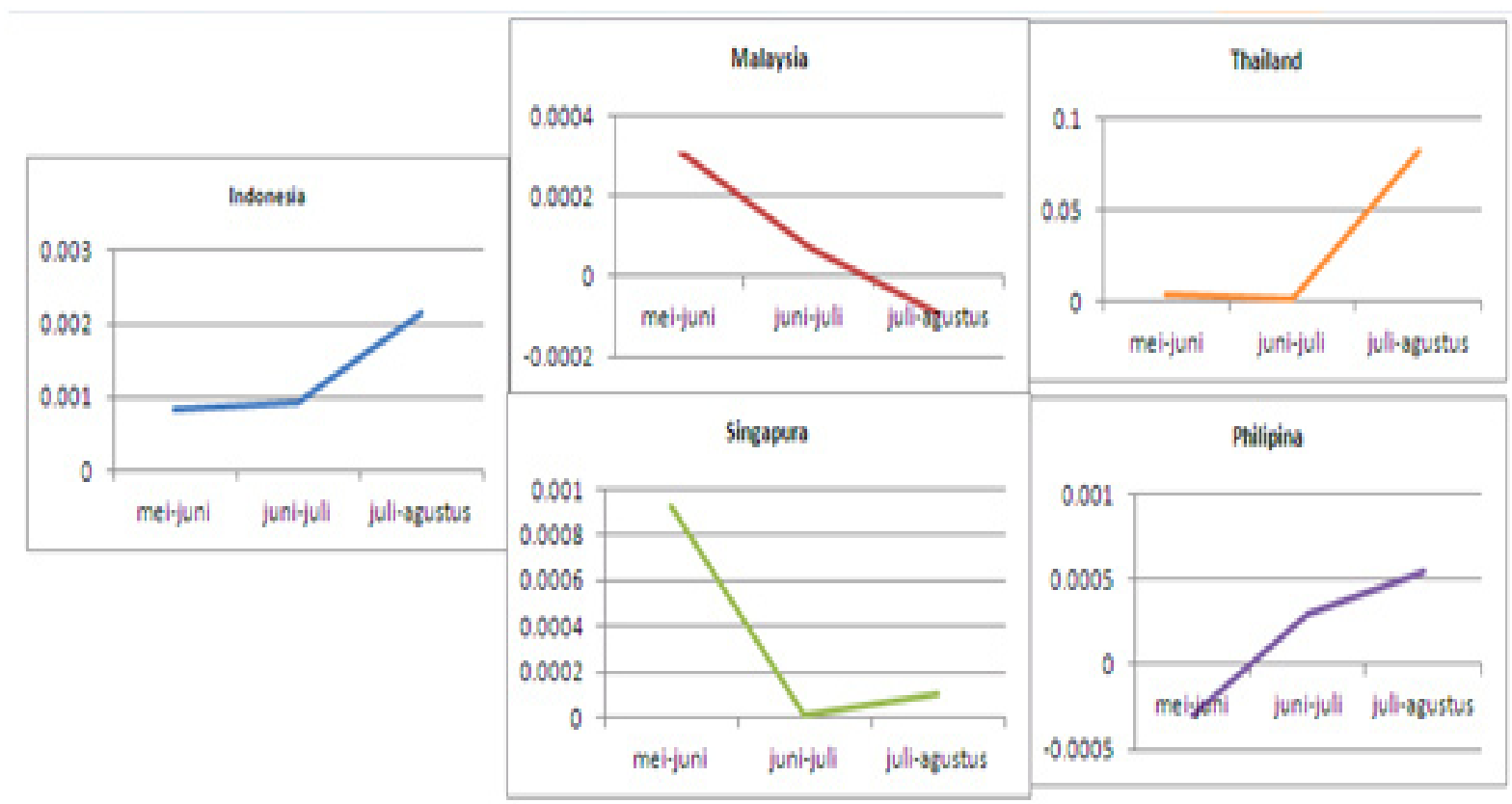

Gambar 1. Grafik Perkembangan Return Saham Periode Mei-Agustus 2014 Pada Pasar Modal ASEAN

Berdasarkan gambar 1 dapat diketahui bahwa return saham di pasar modal ASEAN mengalami reaksi pasar yang berbeda. Saat dimulainya piala dunia, return saham FTSE Bursa Malaysia KLCI ,Singapore Straits Index dan Stock Ecxhange of Thailand 50 mengalami penurunan namun saat menjelang berakhirnya piala dunia, return saham Singapore Straits Index dan Stock Ecxhange of Thailand 50 berangsur kembali meningkat. Sedangkan return saham Indeks LQ 45 dan Philippine Stock Exchange Index dari mulai sebelum piala dunia sampai berakhirnya peristiwa tersebut mengalami peningkatan. Pergerakan return saham Indonesia dalam hal ini diwakili indeks LQ-45 tampak atraktif saham dibanding dengan negara lain. manajemen pada suatu periode, kualitas kinerja ini salah satunya tercermin dalam harga saham perusahaan. Selisih antara harga saham periode sekarang (t) dengan harga saham periode sebelumnya ( $\mathrm{t}-1)$, dibagi dengan harga saham periode sebelumnya (t-1) akan menghasilkan return. Jika harga saham meningkat berarti return saham juga meningkat. Return disajikan pada akun ekuitas dalam neraca, neraca inilah digunakan bagi pihak manajemen untuk mengetahui keseimbangan antara aktiva dengan ekuitas. Peningkatan return akan dipersepsikan oleh emiten sebagai waktu yang tepat untuk melakukan ekspansi, merger, akuisisi, pengeluaran saham baru melalui right issue, melakukan stock split untuk meningkatkan modal yang dapat digunakan 
dalam kegiatan operasional perusahaan.

Semua investor mengetahui bahwa setiap periode piala dunia terjadi reaksi pasar yaitu pergerakan saham melambat, sehingga mengakibatkan nilai return perusahaan menurun, namun penyebabnya tidak tahu persis. Oleh sebab itu, merupakan hal yang menarik bagi peneliti untuk melakukan analisa terjadinya reaksi pasar dalam bentuk return sebelum, selama dan sesudah Piala Dunia pada pasar modal ASEAN.

\section{Telaah Teori Dan Pengembangan Hipotesis}

Ajang piala dunia menjadi sorotan banyak orang tidak terkecuali investor di kawasan ASEAN, dalam kaitan dengan perdagangan saham banyak anggapan bahwa setiap kali dilaksanakan ajang terbesar kejuaraan sepakbola ini terjadi penurunan volume transaksi saham di pasar modal. Ehrman (2012) membuktikan bahwa FIFA World Cup 2010 mengakibatkan penurunan return saham sebesar $20 \%$ di Eropa. Hal ini serupa dengan penelitian Berument (2009) yang menjelaskan bahwa kemenangan pertandingan tiga tim besar di Turki mengakibatkan kenaikan return saham.

Return saham menurut Jogiyanto (2010) terdiri dari capital gain dan dividen. Capital gain adalah keuntungan yang diperoleh pemodal karena selisih harga. Dividen merupakan keuntungan penghasilan yang diberikan oleh para emiten kepada para pemegang saham perusahaannya atas pendapatan oleh perusahaan. Variabel return (capital gain) dapat diukur dengan persamaan sebagai berikut:

$$
R_{i t}=\frac{P_{i t}-P_{i t-1}}{P_{i t-1}}
$$

Dimana :

$\mathrm{R}$ it $\quad=$ Return saham i pada hari ke $\mathrm{t}$

$\mathrm{P}$ it $=$ Harga saham $\mathrm{i}$ pada hari ke $\mathrm{t}$
P it-1 = Harga saham i pada hari ke t-1

Husnan (2005) menjelaskan bahwa terdapat tiga bentuk/tingkatan untuk menyatakan efisiensi pasar modal yang dikemukakan oleh Eugene F Fama pada tahun 1970, yaitu : (1) Efisiensi yang lemah (weak form efficiency), dimana harga-harga mencerminkan semua informasi yang ada pada catatan harga di waktu yang lalu. Dalam keadaan seperti ini pemodal tidak bisa memperoleh tingkat keuntungan di atas normal dengan menggunakan trading rules yang bedasarkan atas informasi harga di waktu yang lalu. (2) Efisiensi setengah kuat (semi strong), dimana harga-harga bukan hanya mencerminkan harga-harga di waktu yang lalu, tetapi semua informasi yang dipublikasikan. Dengan kata lain, para pemodal tidak bisa memperoleh tingkat keuntungan di atas normal dengan memanfaatkan public information. (3) Efisiensi yang kuat (strong forms), dimana harga tidak hanya mencerminkan semua informasi yang dipublikasikan, tetapi juga informasi yang bisa diperoleh dari analisa fundamental tentang perusahaan dan perekonomian. Dalam keadaan semacam ini pasar modal ideal, harga selalu wajar dan tidak ada investor yang mampu memperoleh perkiraan yang lebih baik tentang harga saham.

Jogiyanto (2010) mendefinisikan anomali pasar sebagai teknik atau strategi yang tampaknya bertentangan dengan pasar efisien. Dari sudut pandang Fabozzi (2009) terdapat beberapa jenis anomali pasar yang dapat terjadi, yaitu SmallFirm Effect, Low P-E, Neglected-Firm Effect dan Calender Effect

Penelitian yang sebelumnya dilakukan oleh Palomino (2008) membuktikan bahwa kemenangan tim sepakbola yang listing di London Stock Exchange memberikan efek signifikan terhadap nilai abnormal return sahamnya.

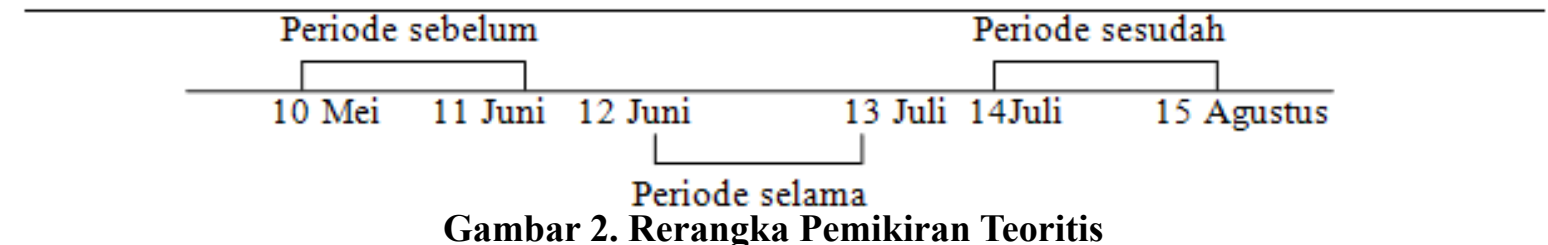

Gambar 2. Rerangka Pemikiran Teoritis 
Berdasarkan latar belakang dan teori yang telah dijelaskan sebelumnya maka secara ringkas rerangka pemikiran dapat dilihat pada gambar 2 . Dari rerangka pemikiran tersebut dapat disusun hipotesis penelitian sebagai berikut:

Ha : Terjadi reaksi pasar dalam bentuk return sebelum, selama dan sesudah peristiwa Piala Dunia tahun 2014 di pasar modal negaranegara ASEAN

\section{Metode}

Penelitian ini merupakan riset kuantitatif dengan sampel perusahaan-perusahaan yang masuk daftar emiten terlikuid di pasar modal ASEAN. Total sampel dianalisis adalah sejumlah 181 emiten yang masuk pada Indeks LQ-45, Straits Times Index, FTSE Bursa Malaysia Index, Stock Exchange of Thailand 50 Index dan Philippine Stock Exchange Index pada periode Mei, Juni, Juli, Agustus tahun 2014. Sumber data dalam penelitian ini berasal dari data sekunder yang dikeluarkan oleh Bursa Efek Indonesia www.idx. co.id, Singapore Exchange www.ftse.com, www. straitstimes.com, FTSE Bursa Malaysia www. ftse.com, Stock Exchange of Thailand www.set. or www.set.or.th dan Philippine Stock Exchange www.ptse.com.

Teknik pengambilan sampel yang digunakan adalah teknik nonprobability sampling, dengan metode purposive sampling, yaitu metode pengambilan sampel nonprobabilitas yang memenuhi kriteria tertentu yang disesuaikan dengan tujuan penelitian (Cooper 2006). Kriteria saham-saham yang akan dilakukan penelitian untuk dijadikan sampel penelitian adalah saham perusahaan yang dipilih yaitu:

1. Saham yang termasuk negara pendiri ASEAN yaitu Indonesia, Singapura, Malaysia, Thailand dan Filipina

2. Saham perusahaan yang termasuk tingkat likuiditasnya tinggi yaitu Indeks LQ-45, Straits Times Index, FTSE Bursa Malaysia Index, Stock Exchange of Thailand Index dan Philippine Stock Exchange Index

3. Saham yang tercatat di di Bursa Efek Indonesia, Singapore Exchange, FTSE Bursa
Malaysia, Stock Exchange of Thailand dan Philippine Stock Exchange selama periode Mei, Juni, Juli, Agustus tahun 2014.

Penelitian ditujukan untuk melihat reaksi pasar selama peristiwa Piala Dunia tahun 2014. Variabel pada penelitian ini adalah return saham. Apabila terdapat hari libur di suatu negara, harga saham yang digunakan adalah harga saham terakhir sebelum libur. Hal ini dilakukan agar tidak ada data yang terbuang.

Prosedur yang dilakukan untuk menguji ada atau tidaknya reaksi pasar dalam bentuk return selama peristiwa piala dunia tahun 2014 di pasar modal ASEAN, adalah sebagai berikut:

1. Menghitung pengembalian saham harian (return) untuk setiap hari yang diamati.

2. Melakukan pengujian reaksi pasar dalam bentuk return selama peristiwa piala dunia tahun 2014 pada pasar modal ASEAN dengan langkah sebagai berikut:

Melakukan uji pengaruh One Sampel T-Test untuk menentukan apakah reaksi pasar dalam bentuk return selama peristiwa piala dunia tahun 2014 di pasar modal ASEAN.

3. Mengambil kesimpulan dengan cara membandingkan nilai $\mathrm{t}$ hitung dengan nilai $\mathrm{t}$ tabel atau nilai signifikansi dengan $\alpha 5 \%$ dan $10 \%$.

\section{Hasil Penelitian dan Pembahasan}

Data yang digunakan dalam penelitian ini merupakan data harian berupa daily adj.close price/harga harian indeks pada saat penutupan dari periode 10 Mei-15 Agustus 2014. Data ini berdasarkan historical price Indeks LQ45, Straits Times Index, FTSE Bursa Malaysia KLCI, Stock Exchange of Thailand 50 Index dan Philippine Stock Exchange Index.

Pengujian periode sebelum terjadi piala dunia dilakukan selama 24 hari pengamatan. Selama 24 hari tersebut di beberapa negara tidak terjadi transaksi perdagangan saham karena libur nasional pada tanggal tersebut. Pada tanggal ini tidak terjadinya transaksi perdagangan saham ditandai dengan not available (na). Di Indonesia 
terdapat 5 na, di Singapura, Malaysia dan Thailand terdapat 2 na, sedangkan di Filipina hanya terdapat 1 na.

Pengujian pada 5 negara yang diamati tersebut terjadinya reaksi pasar selama 24 hari pengamatan dengan nilai signifikansi $5 \%$ dan $10 \%$. Di Indonesia terjadi reaksi pasar sebanyak 14 hari dari 24 hari pengamatan. Singapura sebanyak 9 hari, Malaysia sebanyak 8 hari, Thailand sebanyak 15 hari, dan Filipina sebanyak 10 hari. Terdapat kesamaan hari terjadinya reaksi pasar antara 5 negara pada tanggal 14 Mei dan 10 Juni. Hasil komparasi uji reaksi pasar sebelum piala dunia dapat dilihat pada tabel 1 .
Berdasarkan tabel 1. dapat diketahui bahwa negara Indonesia dan Thailand merupakan negara yang terbesar terjadinya reaksi pasar pada sebelum piala dunia sebanyak 14-15 hari dari 24 hari pengamatan dibandingkan dengan negara Malaysia, Singapura dan Filipina sekitar 8-10 hari.

Pengujian selama terjadi piala dunia dilakukan selama 22 hari pengamatan. Hari pengamatan adalah hari terjadinya reaksi pasar berupa anomali. Selama 22 hari tersebut di beberapa negara terdapat hari tidak terjadi transaksi perdagangan saham karena libur nasional. Pada tanggal tidak terjadinya transaksi

Tabel 1. Hasil Komparasi Uji Reaksi Pasar dalam Bentuk Return Sebelum Piala Dunia Tahun 2014 di Pasar Modal ASEAN

\begin{tabular}{|c|c|c|c|c|c|c|c|c|c|c|c|}
\hline \multirow[t]{2}{*}{ No } & \multirow[t]{2}{*}{ Tanggal } & \multicolumn{2}{|c|}{$\begin{array}{c}\text { INDONESIA } \\
\text { LQ45 (41) }\end{array}$} & \multicolumn{2}{|c|}{$\begin{array}{l}\text { SINGAPURA } \\
\text { SSI (30) }\end{array}$} & \multicolumn{2}{|c|}{$\begin{array}{c}\text { MALAYSIA } \\
\text { FTSE BM (30) }\end{array}$} & \multicolumn{2}{|c|}{$\begin{array}{l}\text { THAILAND } \\
\text { SET50 (50) }\end{array}$} & \multicolumn{2}{|c|}{$\begin{array}{l}\text { FILIPINA } \\
\text { PSEI(30) }\end{array}$} \\
\hline & & t-hit & Sig & t-hit & sig & t-hit & Sig & t-hit & sig & t-hit & Sig \\
\hline 1 & Mei_12 & 3.160 & $.003 *)$ & -.695 & .493 & .978 & .336 & .923 & .360 & -2.271 & .031 \\
\hline 2 & Mei_13 & 1.114 & .272 & na & na & na & na & na & na & na & na \\
\hline 3 & Mei_14 & 6.559 & $\left..000^{*}\right)$ & 4.715 & $\left..000^{*}\right)$ & 4.869 & $\left..000^{*}\right)$ & 4.726 & $\left..000^{*}\right)$ & 3.468 & $.002 *)$ \\
\hline 4 & Mei_15 & na & na & 1.759 & $\left..089^{* *}\right)$ & -.416 & .680 & .383 & .703 & .910 & .370 \\
\hline 5 & Mei_16 & 2.245 & $\left..030^{*}\right)$ & -2.342 & $\left..026^{*}\right)$ & 1.542 & .134 & 2.870 & $\left..006^{*}\right)$ & -1.685 & .103 \\
\hline 6 & Mei_19 & -3.312 & $.002 *)$ & .835 & .411 & .921 & .365 & 3.995 & $.000 *)$ & -2.324 & $\left..027^{*}\right)$ \\
\hline 7 & Mei_20 & -7.655 & $.000 *)$ & -.136 & .893 & -2.173 & $\left..038^{*}\right)$ & -4.505 & $.000 *)$ & 1.190 & .244 \\
\hline 8 & Mei_21 & 2.391 & $.022 *)$ & -.316 & .755 & -.597 & .555 & 3.609 & $\left..001^{*}\right)$ & .368 & .716 \\
\hline 9 & Mei_22 & 7.046 & $\left..000^{*}\right)$ & .567 & .575 & -.877 & .388 & .740 & .463 & -7.913 & $.000 *)$ \\
\hline 10 & Mei_23 & .917 & .365 & 2.351 & $\left..026^{*}\right)$ & -1.246 & .223 & -2.895 & $\left..006^{*}\right)$ & 6.778 & $.000 *)$ \\
\hline 11 & Mei_26 & -2.546 & $\left..015^{*}\right)$ & .585 & .563 & -2.508 & $\left..018^{*}\right)$ & -1.634 & .109 & -1.484 & .149 \\
\hline 12 & Mei_27 & na & na & -.173 & .864 & 2.356 & $\left..025^{*}\right)$ & 2.368 & $.022 *)$ & -1.954 & $.060 * *)$ \\
\hline 13 & Mei_28 & 1.692 & $.098 * *)$ & -.124 & .902 & .764 & .451 & 4.945 & $\left..000^{*}\right)$ & -.240 & .812 \\
\hline 14 & Mei_29 & na & na & 6.229 & $\left..000^{*}\right)$ & 1.606 & .119 & 1.994 & .052 & .903 & .374 \\
\hline 15 & Mei_30 & -3.144 & $\left..003^{*}\right)$ & -1.588 & .123 & -2.260 & $\left..031^{*}\right)$ & 2.567 & $\left..013^{*}\right)$ & -5.897 & $.000 *)$ \\
\hline 16 & Juni_2 & -.551 & .585 & -.160 & .874 & -.573 & .571 & 7.668 & $\left..000^{*}\right)$ & -.896 & .377 \\
\hline 17 & Juni_3 & 3.688 & $\left..001^{*}\right)$ & -.545 & .590 & 2.576 & $\left..015^{*}\right)$ & 4.561 & $\left..000^{*}\right)$ & 3.375 & $.002 *)$ \\
\hline 18 & Juni_4 & -. .995 & .326 & -2.118 & $\left..043^{*}\right)$ & -2.743 & $\left..010^{*}\right)$ & -2.264 & $.028 *)$ & 4.928 & $.000 *)$ \\
\hline 19 & Juni_5 & .935 & .356 & 1.536 & .135 & 1.039 & .307 & 1.742 & $\left..088^{* *}\right)$ & -.524 & .605 \\
\hline 20 & Juni_6 & -.505 & .616 & 3.419 & $\left..002^{*}\right)$ & -.636 & .530 & 2.544 & $.014 *)$ & .509 & .615 \\
\hline 21 & Juni_7 & na & na & na & na & na & na & na & na & -.849 & .403 \\
\hline 22 & Juni_9 & -5.361 & $\left..000^{*}\right)$ & 1.835 & $\left..077^{* *}\right)$ & -.619 & .540 & -.182 & .857 & 2.087 & $\left..046^{*}\right)$ \\
\hline 23 & Juni_10 & 6.061 & $.000 *)$ & -3.328 & $.002 *)$ & 3.458 & $.002 *)$ & 4.166 & $\left..000^{*}\right)$ & -1.878 & $.071 * *)$ \\
\hline 24 & Juni_11 & 3.686 & $.001 *)$ & -.995 & .328 & 1.241 & .225 & -.978 & .333 & 1.625 & .115 \\
\hline
\end{tabular}

Keterangan:

*) $\operatorname{sig} 0,05$;

**) $\operatorname{sig} 0,10$

Sumber: Data Diolah, 2015 
perdagangan saham ditandai dengan not available (na). Di Thailand terdapat 2 na, dan di Filipina hanya terdapat 1 na.

Pengujian pada 5 negara yang diamati selama 22 hari pengamatan dengan nilai signifikansi $5 \%$ dan $10 \%$ di Indonesia terjadi reaksi pasar sebanyak 17 hari, Singapura sebanyak 7 hari, Malaysia sebanyak 10 hari, Thailand sebanyak 10 hari, dan Filipina sebanyak 13 hari. Terdapat kesamaan hari terjadinya reaksi pasar antara 5 negara yaitu pada tanggal 16 Juni dan 27 Juni. Hasil komparasi uji reaksi pasar selama piala dunia dapat dilihat pada tabel 2 .
Berdasarkan tabel di atas dapat diketahui bahwa negara Indonesia merupakan negara yang terbesar terjadinya reaksi pasar selama piala dunia sebanyak 17 hari dari 22 hari pengamatan dibandingkan dengan negara lain sekitar 7-14 hari.

Pada pengujian ketiga yaitu periode sesudah piala dunia dilakukan selama 25 hari pengamatan. Di Indonesia terdapat 5 na, di Singapura dan Filipina terdapat 1 na, Malaysia dan Thailand terdapat 2 na. Pada pengujian ini Indonesia, Thailand, Filipina terjadi reaksi pasar sebanyak 11 hari dari 25 hari pengamatan.

Tabel 2. Hasil Komparasi Uji Reaksi Pasar dalam Bentuk Return Selama Piala Dunia Tahun 2014 di Pasar Modal ASEAN

\begin{tabular}{|c|c|c|c|c|c|c|c|c|c|c|c|}
\hline \multirow[t]{2}{*}{ No } & \multirow[t]{2}{*}{ Tanggal } & \multicolumn{2}{|c|}{$\begin{array}{c}\text { INDONESIA } \\
\text { LQ45 (41) }\end{array}$} & \multicolumn{2}{|c|}{$\begin{array}{c}\text { SINGAPURA } \\
\text { SSI (30) } \\
\end{array}$} & \multicolumn{2}{|c|}{$\begin{array}{c}\text { MALAYSIA } \\
\text { FTSE BM (30) }\end{array}$} & \multicolumn{2}{|c|}{$\begin{array}{c}\text { THAILAND } \\
\text { SET50 (50) }\end{array}$} & \multicolumn{2}{|c|}{$\begin{array}{c}\text { FILIPINA } \\
\text { PSEI(30) } \\
\end{array}$} \\
\hline & & t-hit & sig & t-hit & Sig & t-hit & Sig & t-hit & sig & t-hit & sig \\
\hline 1 & Juni_12 & -2.853 & $.007 *)$ & 1.478 & .150 & -2.590 & $\left..015^{*}\right)$ & -2.801 & $.007 *)$ & na & na \\
\hline 2 & Juni_13 & -.243 & .809 & -1.433 & .162 & 1.741 & $.092 * *)$ & .041 & .967 & -2.720 & $.011 *)$ \\
\hline 3 & Juni_16 & -4.989 & $.000 *)$ & -1.503 & .144 & -1.865 & $.072 * *)$ & 2.299 & $\left..026^{*}\right)$ & -1.734 & $.093 * *)$ \\
\hline 4 & Juni_17 & 2.351 & $.024 *)$ & -4.219 & $.000 *)$ & .906 & .372 & .730 & .469 & -2.958 & $.006 *)$ \\
\hline 5 & & -3.938 & $.000 *)$ & .720 & 477 & -.450 & .656 & -7.909 & $.000 *)$ & -.164 & .870 \\
\hline 6 & Juni_19 & -4.069 & $.000 *)$ & -1.005 & .323 & 1.408 & .170 & 3.591 & $.001 *)$ & -.592 & .559 \\
\hline 7 & Juni_20 & -1.065 & .293 & -2.729 & $.011 *)$ & 1.210 & .236 & .913 & .366 & 1.412 & .169 \\
\hline 8 & Juni_23 & -3.328 & $.002 *)$ & .921 & .365 & -.417 & .680 & -.207 & .837 & 1.560 & .130 \\
\hline 9 & & 1.703 & $.096 * *)$ & .576 & .569 & 3.689 & $.001 *)$ & -3.566 & $.001 *)$ & 2.470 & $.020 *)$ \\
\hline 10 & Juni_25 & -1.109 & .274 & -.213 & .833 & -1.780 & $.086 * *)$ & 4.267 & $.000 *)$ & 1.587 & .123 \\
\hline 11 & Juni_26 & 3.606 & $.001 *)$ & 3.978 & $.000 *)$ & .272 & .788 & 2.073 & $\left..043^{*}\right)$ & 3.783 & $.001 *)$ \\
\hline 12 & Juni_27 & -2.774 & $.008 *)$ & -1.987 & $.056 * *)$ & -3.358 & $.002 *)$ & 3.061 & $\left..004^{*}\right)$ & -2.662 & $\left..013^{*}\right)$ \\
\hline 13 & Juni_30 & 3.474 & $.001 *)$ & -.769 & .448 & 1.350 & .187 & -.629 & .532 & -.457 & .651 \\
\hline 14 & Juli_1 & -1.812 & $.077 * *)$ & -4.000 & $.000 *)$ & -1.796 & $\left..083^{* *}\right)$ & na & na & -1.543 & .134 \\
\hline 15 & Juli_2 & 3.766 & $.001 *)$ & 4.722 & $.000 *)$ & 3.807 & $.001 *)$ & 1.373 & .176 & 1.648 & .110 \\
\hline 16 & & 1.587 & .120 & 1.638 & .112 & .785 & .439 & .965 & .340 & 1.913 & $.066 * *)$ \\
\hline 17 & Juli_4 & 2.517 & $.016 *)$ & -1.365 & .183 & -1.320 & .197 & 1.343 & .186 & 4.916 & $.000 *)$ \\
\hline 18 & Juli_7 & 6.844 & $.000 *)$ & 3.049 & .005 & 2.761 & $\left..010^{*}\right)$ & .831 & .410 & 3.050 & $\left..005^{*}\right)$ \\
\hline 19 & Juli_8 & 2.274 & $.028 *)$ & -1.325 & .196 & .090 & .929 & 3.026 & $.004 *)$ & -3.451 & $.002 *)$ \\
\hline 20 & Juli_9 & 1.000 & .326 & -1.057 & .299 & -.711 & .483 & -.515 & .609 & -3.497 & $.002 *)$ \\
\hline 21 & Juli_10 & 4.457 & $.000 *)$ & .513 & .612 & .694 & .493 & 4.099 & $.000 *)$ & 3.920 & $.000 *)$ \\
\hline 22 & Juli_11 & -5.946 & $.000 *)$ & 2.015 & $.053 * *)$ & -1.764 & $\left..088^{* *}\right)$ & na & na & -2.216 & $.035 *)$ \\
\hline
\end{tabular}

Keterangan :

*) sig 0,05

**) sig 0,10

Sumber: Data Diolah, 2015 
Singapura sebanyak 10 hari, Malaysia sebanyak 8 hari. Terdapat kesamaan hari terjadinya reaksi pasar antara 5 negara pada tanggal 4 Agustus. Dapat dilihat pada tabel 3. reaksi pasar pada sebelum piala dunia sebanyak 11 hari dari 25 hari pengamatan dibandingkan dengan negara Malaysia dan Singapura sekitar 8-10 hari.

Tabel 3. Hasil Komparasi Uji Reaksi Pasar dalam Bentuk Return Selama Piala Dunia Tahun 2014 di Pasar Modal ASEAN

\begin{tabular}{|c|c|c|c|c|c|c|c|c|c|c|c|}
\hline \multirow[t]{2}{*}{ No } & \multirow[t]{2}{*}{ Tanggal } & \multicolumn{2}{|c|}{$\begin{array}{c}\text { INDONESIA } \\
\text { LQ45 (41) }\end{array}$} & \multicolumn{2}{|c|}{$\begin{array}{c}\text { SINGAPURA } \\
\text { SSI (30) }\end{array}$} & \multicolumn{2}{|c|}{$\begin{array}{c}\text { MALAYSIA } \\
\text { FTSE BM (30) }\end{array}$} & \multicolumn{2}{|c|}{$\begin{array}{l}\text { THAILAND } \\
\text { SET50 (50) }\end{array}$} & \multicolumn{2}{|c|}{$\begin{array}{c}\text { PHILIPINA } \\
\text { PSEI(30) }\end{array}$} \\
\hline & & t-hit & sig & t-hit & sig & t-hit & Sig & t-hit & sig & t-hit & sig \\
\hline 1 & Juli_14 & -.266 & .792 & -.602 & .552 & .704 & .487 & 3.438 & $.001 *)$ & -5.306 & $.000 *)$ \\
\hline 2 & Juli_15 & 3.036 & $.004 *)$ & .310 & .759 & na & na & -1.422 & .161 & 1.013 & .319 \\
\hline 3 & Juli_16 & 3.724 & $.001 *)$ & 3.090 & $\left..004^{*}\right)$ & 1.507 & .143 & 2.301 & $\left..026^{*}\right)$ & na & na \\
\hline 4 & Juli_17 & -5.114 & $.000 *)$ & 1.145 & .261 & -.654 & .518 & 1.522 & .134 & 1.675 & .105 \\
\hline 5 & Juli_18 & 2.952 & $.005 *)$ & 2.085 & $\left..046^{*}\right)$ & -5.249 & $.000 *)$ & .044 & .965 & -1.526 & .138 \\
\hline 6 & Juli_21 & 4.304 & $\left..000^{*}\right)$ & .930 & .360 & -1.575 & .126 & 1.086 & .283 & 2.035 & $\left..051^{*}\right)$ \\
\hline 7 & Juli_22 & -4.593 & $\left..000^{*}\right)$ & 1.183 & .247 & 1.039 & .307 & -5.366 & $.000 *)$ & -.548 & .588 \\
\hline 8 & Juli_23 & .438 & .664 & 3.334 & $.002 *)$ & -.035 & .973 & 6.916 & $.000 *)$ & 1.053 & .301 \\
\hline 9 & Juli_24 & -.322 & .749 & 3.577 & $\left..001^{*}\right)$ & 1.085 & .287 & 1.384 & .173 & -.208 & .836 \\
\hline 10 & Juli_25 & -1.430 & .160 & -.937 & .356 & 1.435 & .162 & .213 & .832 & .216 & .831 \\
\hline 11 & Juli_28 & na & $\mathrm{Na}$ & na & na & na & na & -.678 & .501 & -3.238 & $.003 *)$ \\
\hline 12 & Juli_29 & na & $\mathrm{Na}$ & -1.052 & .302 & na & na & -5.017 & $\left..000^{*}\right)$ & na & na \\
\hline 13 & Juli_30 & na & $\mathrm{Na}$ & -3.237 & $\left..003^{*}\right)$ & .682 & .501 & -.375 & .709 & -.464 & .646 \\
\hline 14 & Juli_31 & na & na & 1.693 & .101 & -2.779 & $.009 *)$ & -3.884 & $.000 *)$ & .230 & .820 \\
\hline 15 & Agustus_1 & na & na & -3.023 & $\left..005^{*}\right)$ & -3.244 & $.003 *)$ & -1.657 & .104 & 2.562 & $\left..016^{*}\right)$ \\
\hline 16 & Agustus_4 & 2.665 & $\left..011^{*}\right)$ & -3.239 & $.003 *)$ & 3.268 & $.003 *)$ & 4.520 & $.000 *)$ & 6.365 & $.000 *)$ \\
\hline 17 & Agustus_5 & 1.316 & .196 & .704 & .487 & .875 & .389 & 2.189 & $\left..033^{*}\right)$ & -.766 & .450 \\
\hline 18 & Agustus_6 & -4.841 & $\left..000^{*}\right)$ & -1.390 & .175 & -3.152 & $\left..004^{*}\right)$ & -1.965 & $\left..055^{* *}\right)$ & -1.337 & .191 \\
\hline 19 & Agustus_7 & -.711 & .481 & -1.332 & .193 & -.343 & .734 & .763 & .449 & 1.858 & $\left..073^{* *}\right)$ \\
\hline 20 & Agustus_8 & -.957 & .344 & -4.121 & $.000 *)$ & -5.762 & $.000 *)$ & -.693 & .491 & -5.207 & $.000 *)$ \\
\hline 21 & Agustus_11 & 5.307 & $.000 *)$ & 1.957 & $\left..060^{* *}\right)$ & 4.998 & $.000 *)$ & na & na & 3.718 & $.001 *)$ \\
\hline 22 & Agustus_12 & 2.731 & $.009 *)$ & -.331 & .743 & -.020 & .984 & na & na & 1.946 & $\left..061^{* *}\right)$ \\
\hline 23 & Agustus_13 & 5.347 & $.000 *)$ & .966 & .342 & 3.153 & $\left..004^{*}\right)$ & 6.238 & $.000 *)$ & -.768 & .449 \\
\hline 24 & Agustus_14 & -1.047 & .302 & -1.115 & .274 & .716 & .480 & .524 & .603 & 3.798 & $\left..001^{*}\right)$ \\
\hline 25 & Agustus_15 & .143 & .887 & 4.383 & $.000 *)$ & 1.084 & .287 & 2.132 & $\left..038^{*}\right)$ & -4.514 & $.000 *)$ \\
\hline
\end{tabular}

Keterangan:

*) sig 0,005 .**) sig 0,10

Sumber: Data Diolah, 2015

Berdasarkan tabel 3 dapat diketahui bahwa negara Indonesia, Thailand dan Thailand merupakan negara yang terbesar terjadinya 
Tabel 4. Hasil Komparasi Uji Reaksi Pasar dalam Bentuk Return Sebelum, Selama dan Sesudah Piala Dunia tahun 2014 pada Pasar Modal ASEAN

\begin{tabular}{lcccccc}
\hline \multirow{2}{*}{ Negara } & \multicolumn{2}{c}{ Sebelum (24 hari) } & \multicolumn{2}{c}{ Selama (22 hari) } & \multicolumn{2}{c}{ Sesudah (25 hari) } \\
& na & Jml Hari & na & Jml Hari & na & Jml Hari \\
\hline Indonesia & 3 & 14 & & 17 & 5 & 11 \\
Singapura & 2 & 9 & & 7 & 1 & 10 \\
Malaysia & 2 & 8 & & 10 & 2 & 8 \\
Thailand & 2 & 15 & 2 & 10 & 2 & 11 \\
Filipina & 1 & 10 & 1 & 13 & 1 & 11 \\
\hline
\end{tabular}

Sumber: Data Diolah, 2015

Berdasarkan ketiga pengujian yang telah dilakukan dapat diketahui bahwa selama periode pengamatan, pasar modal Indonesia dan Thailand sangat bereaksi terhadap peristiwa piala dunia tahun 2014. Hal ini berarti karakteristik pasar modal Indonesia dan Thailand dipengaruhi informasi yang terkait dengan analisis teknikal seperti peristiwa politik, keadaan ekonomi makro dan peristiwa besar lainnya dalam pengambilan keputusan investasi.

Hasil penelitian ini sejalan dengan Kaplanski (2013) yang membuktikan bahwa faktor-faktor non ekonomi seperti olahraga memberikan efek signifikan terhadap return saham dan ekspetasi risiko di pasar modal Belanda.

\section{Kesimpulan, Keterbatasan, dan Implikasi Hasil Penelitian}

Penelitian inibertujuan untuk menganalisa terjadinya reaksi pasar dalam bentuk return sebelum, selama dan sesudah piala dunia tahun 2014 pada pasar modal ASEAN, yaitu Indonesia, Singapura, Malaysia, Thailand dan Filipina. Berdasarkan hasil pengujian One Sample T-Test terhadap indeks LQ-45, STI, FTSE BM KLCI, SET 50, PSEI dapat disimpulkan bahwa pasar modal Indonesia dan Thailand sangat bereaksi terhadap peristiwa piala dunia tahun 2014.

Keterbatasan yang terdapat dalam penelitian ini adalah variabel penelitian yang digunakan hanya return aktual saham (capital gain). Adapun saran dalam penelitian ini ditujukan untuk peneliti selanjutnya yaitu penambahan penggunaan variabel penelitian yang akan diuji seperti menggunakan deviden saham, abnormal return, danvolume perdagangansaham. Kemudian pengukuran variabel return dapat menggunakan opening price dalam perhitungannya yaitu dengan mengurangkan close price dengan opening price. Sedangkan saran kepada investor untuk memperhatikan reaksi pasar saat terjadinya suatu peristiwa yang dapat mempengaruhi dalam menentukan keputusan transaksi saham.

\section{Daftar Pustaka}

Bell, Adrian. 2010. Over the Mean or Sick as a Parrot? The Effects of Football Results on a Clubs Share Price. Journal Applied Economic.

Berument, Hakan. 2006. Perfomance of Soccer on the Stock Market: Evidence From Turkey. The Social Science Journal 695-699.

Berument, M.H, et al. 2009. Soccer, Stock Return and Fanaticism: Evidence From Turkey. The Social Science Journal 46, 594-600

Berument, M.H and Nildag B. 2012. The Social Science Journal 49, 368-374.

Boido, Claudian and Antonio F. Football and Mood in Italian Stock Exchange. JEL Classification 614: D18.

Cooper, Donald R and Schindle, Pamela S. 2006. Metode Riset Bisnis, Volume 2. Jakarta: PT. Media Global Edukasi

Dohmen, Thomas, etal.2006. SeeminglyIrrelevant Events Affect Economic Perceptions and Expectations: the FIFA World Cup 2006 as a Natural Experiment. IZA Discusion Paper 
No 2275.

Ehrman, Mand David J.2012. Investor Inattention During FIFA World Cup Matches. Working Paper Series No 1424.

Elisabete and Viera. 2012. Investor Sentiment and Market Reaction: Evidence on 2010 FIFA World Cup. Journal Economics and Accounting Vol 3 No 12012.

Fabozzi, F. J., and Modigliani, F. 2009. Capital Market: Institution and Instrument 4th edition. New Jersey: Pretice Hall

Fama, Eugene. 1970. Efficiency Market: A Review of Theory and Empirical Work. Journal of Finance, 25(3), 383-417

Harahap, ID. 2010. Analisis FIFA World Cup Effect terhadap Return dan Volatilitas IHSG di BEI Periode 1994, 1998, 2002, 2006 dan 2010. Jakarta: Universitas Indonesia.

Husnan, Suad. 2005. Dasar-Dasar Teori Portofolio dan Analisis Sekuritas. Edisi Empat. Yogyakarta:UPP AMP YKPN

Jogiyanto, HM, 2010. Teori Portofolio dan Analisis Investasi. Edisi 7. Yogyakarta: BPFE

Jones. 2010. Investment Principle and Concept. Eleven Edition. John Wiley\&Sons, Inc

Jorgensen, et al. 2012. The News Model of Asset Price Determination An Empirical Examination of The Danish Fotball Club. Discussion Paper No. 313. ISSN 18600921

Kaplanski, Buy and Haim Levy. 2008. Exploitable Predictable Irrationality : The FIFA World Cup Effect on The US Stock Market. Jurnal of Financial and Quantitative Analysis Forthcoming.

Kaplanski, Guy, et all. 2013. Do Happy People Make Optimistic Investors?.Journal of Financial and Quantitative Analysis.

Lozano, Fernando. 2009. The Flexibility of the Workweek in the United States (AS) Evidence From the FIFA World Cup. IZA Discussion Paper No 4217.

Palamino, Frederic and Luc Renneboog. 2005. Stock Price Reactions to Short Lived Public Information the Case of Betting Odds. TILEC Discussion Paper ISSN 1572-4042.

Palamino, Frederic, et al. 2008. Information
Salience, Investor Sentiment and Stock Returns: the Case of British Soccer Betting. Forthcoming Journal of Corporate Finance. ISSN 0924-7815.

Scholtens, B and Witje, P. 2007. Scoring on the Stock Exchange? The Effect of Football Matches on Stock Market Return: on Event Study. Journal Applied Economics.

Stadtmann, Georg. 2005. Frequens News and Pure Signals the Case of a Publicly Traded Football Club.USA: Indiana Uni 